\title{
Aurelio Miró Quesada Sosa (1907-1998)
}

\author{
Augusto Alcocer Martínez
}

Pocos días atrás, el sábado 26 de septiembre, la Universidad Nacional Mayor de San Marcos y nuestra Facultad de Letras ha perdido a un hombre que, por encima de su mucho saber, eficaz magisterio y valiosa obra, era un preclaro ejemplo de humanidad. Con Aurelio Miró Quesada Sosa desaparece uno de los últimos representantes de una generación de egregios actores en el campo de la Historia, Literatura, el Periodismo, y con él, lo que hay que resaltar, una brillante época sanmarquina.

Aurelio Miró Quesäda había nacido en la ciúdad de Lima, el 15 de mayo de 1907, cuatro años después que el historiador de la República Jorge Basadre, en Tacna y diecisiete meses antes que el poeta Martín Adán, en Lima. De Miró Quesada, apunta Luis Alberto Sánchez: "Situado en una singular posición intelectual, más cerca de la idea de la promoción 'arielista' o 'novecentista' y de la de 1930, que de la suya propia, aparece con sobriedad de estilo".

Cursó don Aurelio sus estudios de primera y segunda enseñanza en su ciudad natal (1915-1923) como alumno de los Padres Jesuitas. Comenzó sus estudios universitarios y los concluyó en la Facultad de Letras de San Marcos donde se doctoró (1935). Fue en el seno de la cuatricentenaria casa que Miró Quesada se inició en la práctica investigadora y probó su vocación por los estudios de historia literaria. Trasladóse más tarde a la Facultad de Derecho hasta alcanzar el título de abogado (1931). 
Incorporado a la docencia universitaria sanmarquina asumió durante más de dos décadas la cátedra que, según Armando Nieto, S.J., "mejor podría él regentar: Historia de la Literatura Española. Quienes fueron sus alumnos gustaron de los profundos conocimientos y erudición que lucían las lecciones del novel catedrático. Miró Quesada introducía con seguridad a sus discípulos en el aprecio de los clásicos del Siglo de Oro [...] y se esmeraba en buscar trazas de los peruano y americano en las páginas de los grandes autores castellanos. De esas investigaciones surgieron libros medulares como América en el teatro de Lope de Vega (1935), Cervantes, Tirso y el Perú (1947), Lope de Vega y el Perú (1962)".

En el año de 1938, inspirado en el modelo de Paisajes peruanos de José de la Riva-Agüero, publicó Costa, Sierra y Montaña. Aparecen después los libros dedicados a la obra del Inca Garcilaso $(1945,1948,1971,1994)$ que consagran nacional e internacionalmente a Miró Quesada como autorizado biógrafo y estudioso garcilasista.

Al término del mandato del Dr. José Jiménez Borja, con el mayoritario respaldo de la Junta de Catedráticos, la Facultad de Letras en su sesión del 24 de marzo de 1949 -reconociendo las altas calidades intelectuales y honestidad moral- eligió Decano Titular al Dr. Aurelio Miró Quesada quien venía desempeñando el Decanato interinamente desde el 8 de noviembre de 1948.

El 8 de mayo deig56 Laño-agitado-saliốtelegido Rector de San Marcos por una amplia mayoríaquetestimoniabai el prestegióalcanzado y la capacidad para liderar. Al cabo de un año de gestión desarrolló la infraestructura de la entonces naciente Ciudad Universitaria, adelantó un Estatuto Universitario, logró incrementos presupuestales que permitieron aumentar los haberes a los estamentos docentes y administrativos. La Facultad de Letras al verse privada del valioso concurso del Dr. Aurelio Miró Quesada, quien desde la cátedra y desde los altos cargos que desempeñó había prestado a la Universidad valiosos servicios acordó en 1957, en acto de justicia, designarlo Catedrático Honorario.

Damos por finalizado el honroso encargo citando las palabras ofrecidas por el Doctor Miró Quesada el pasado mes de mayo en que la Universidad lo declaró Rector Honorario de San Marcos. "Me emociona estar aquí, donde he pasado muchos años de mi vida, 34 para ser más exacto, en los cuales fui alumno, profesor, decano y por un tiempo rector. Estos 34 años de mi vida son los que más me honran. Siempre me he sentido hombre de San Marcos". 